\title{
The Community Integration of New Residents in the Community Reorganization at a Heritage Site: A Model Based on Tangkou in Huangshan
}

\author{
Wenzhi Wu *, Yuxi Dai and Fudong Qiu \\ Faculty of Economics and Management, East China Normal University, Shanghai 200062, China; \\ 51174402020@stu.ecnu.edu.cn (Y.D.); fdqiu@tour.ecnu.edu.cn (F.Q.) \\ * Correspondence: wzwu@tour.ecnu.edu.cn
}

check for updates

Citation: Wu, W.; Dai, Y.; Qiu, F. The Community Integration of New Residents in the Community

Reorganization at a Heritage Site: A Model Based on Tangkou in Huangshan. Sustainability 2021, 13, 4621. https://doi.org/10.3390/ su13094621

Academic Editors: Asterios Bakolas and Marc A. Rosen

Received: 1 March 2021

Accepted: 13 April 2021

Published: 21 April 2021

Publisher's Note: MDPI stays neutral with regard to jurisdictional claims in published maps and institutional affiliations.

Copyright: (C) 2021 by the authors. Licensee MDPI, Basel, Switzerland. This article is an open access article distributed under the terms and conditions of the Creative Commons Attribution (CC BY) license (https:/ / creativecommons.org/licenses/by/ $4.0 /)$.

\begin{abstract}
With the transition of a heritage community from a living community to one based on servicing tourists, an influx of new residents seeking to run businesses and work in the tourism sector generates an intense process of community reorganization. In turn, changes in the external environment that take place during this community restructuring combine with psychological factors to affect the integration of these new residents. Based on an investigation of Tangkou town in the Huangshan district, a theoretical model of the factors in the community integration of new residents of a heritage site was constructed using a grounded theory approach. Three external factors such as support for the government, economic integration, and community environment and one internal factor was psychological integration were identified as affecting new residents' community integration. The model shows that the external factors influence the psychology of new residents, generating a sense either of closeness or of alienation and affecting their community integration behavior accordingly. In the process of community restructuring, heritage sites might benefit from the smoother integration of new residents, so we should give full play to the participation and driving role of external business entities, and looking to improve the community environment.
\end{abstract}

Keywords: community integration; community reorganization; heritage site; Huangshan Tangkou town; new residents

\section{Introduction}

China currently has 55 world cultural and natural heritage sites, which have become popular tourist destinations. Over thousands of years, rural societies were formed in China and maintained by blood ties. The residents of heritage sites have lived in an "acquaintance society" for generations, based on the personal relationships developed through sharing daily life. In rural societies, the native residents often live by an abiding code of conduct that covers their material and spiritual lives. The code of conduct at the material level dictates the way that material resources are used and shared in local society; the spiritual code of conduct mainly refers to an informal system that has evolved through the longterm social interactions of rural residents. These codes can differ from the formal system of national policies and laws in values, customs, ethics, morality, and ideology. With the rapid development of the tourism industry, the heritage site community bears the traditional residential and production functions. At the same time, new business forms and new cultures disrupt these traditional social relations, which affects the community integration and the nature of social exchange [1]. In particular, to serve the development of heritage tourism, heritage sites community service functions are constantly adjusted, the community's population mobility is accelerated, and the community is prompted to restructure. Large numbers of external tourism service and tourism management personnel move in to the community and become new residents of the tourism destinations as they seek to settle in for the long term. However, new residents who move into a heritage site 
in pursuit of economic benefits bring with them different ideologies and values to those held by local residents, and use the resources of the heritage site differently. This process of new residents moving into the community at a heritage site and living together with native residents can produce many social problems. The changes affect new residents, native residents, and the character of local society.

The entry of new residents and migration of native residents is bound to break the balance of the original community relations, and native residents in the process of community restructuring experience changes in their way of life. Meanwhile, new residents must integrate into an unfamiliar community. The attitude of native residents toward new residents and the nature of the social interactions between them affect the integration of new residents into the community. The arrival of new residents in traditional communities is likely to produce rejection, conflict, and a series of social integration problems. In recent years, China has attached great importance to the governance of urban and rural communities and the construction of harmonious communities, but there are still many difficulties in coordinating relationships between community residents. As a particular form of community development, the coordination of the relationship between new residents and native residents in heritage tourism sites to assist with integration and construct a harmonious community is an urgent problem. Although many scholars have recognized the importance of community integration and much research has been carried out on the topic, the main focus of studies of the community integration of new residents has been on migrant workers moving to urban areas. There has been less research into the community integration of new residents in heritage tourist sites. This article therefore attends to the heritage site community restructuring process, using a grounded theory approach to identify the factors influencing the integration of new residents in a rural community being developed as a tourist destination, and the mechanism behind the effects of these factors. In this way, this study enriches the theory of community integration and addresses the problem of constructing harmonious communities through the successful integration of new residents in traditional societies at heritage sites.

\section{Literature Review}

\subsection{Community Integration of Immigrants}

Research on community integration can be traced back to the concept of social integration put forward by Durkheim at the end of the 19th century [2]. On this basis, scholars have mainly focused on new immigrants in the United States, examining how they have adapted to their new environment with reference to the community fusion, attribution theory, etc. Some non-traditional social integration theories have been developed, including multiculturalism and regional integration [3-8]. Since the 1950s, Western countries have experienced rapid economic development, and the gap between the rich and poor has further widened. This has resulted in the creation of many "slums." With the development of new transportation modes and the narrowing of spatial distances, population mobility became inevitable $[9,10]$. At the same time, spatial isolation and social exclusion are common, and have attracted the attention of scholars in the field [11]. In the 21st century, studies of community integration have become more specific. Bauder et al. [12] found that housing patterns had a significant impact on community integration. Stronger community cohesion was also associated with more diverse immigrant groups and more frequent group exchanges. Yetim et al. [13] found that the degree of new inhabitants' integration into the new community was closely related to the cultural differences between the two communities. The degree of integration then has an impact on the personal happiness of the new inhabitants. Brown [14] observed higher levels of community integration among immigrants to Canada who owned their own homes or had been renting for a long period and among those with a high socio-economic status.

In China, research on community integration started relatively late, not appearing until the mid-1990s. At this time, Chinese scholars began to pay attention to social and community integration with the emergence of an urban floating population. The line of 
research focused more on the macro issues of social integration and less on the micro issues of community integration. Since the beginning of the 21st century, an increasing number of studies have been conducted on the social integration of the floating population, especially migrant workers and their parents and children. Multiple dimensions of social integration have been identified. Tian [15] divided social integration into economic, social, psychological, and cultural aspects. Zhou [16] added to these the two dimensions of structure and identity. Liang et al. [5] put forward a four-dimensional model of Western community integration, comprising economic, social, political, and cultural dimensions. Economic integration includes income level and labor welfare; social integration includes community relationships and friendships; political integration includes election rights and party participation; and cultural integration includes habits and language. Yang [17] made a detailed analysis of the above four dimensions and further proposed the integration process roadmap.

Many scholars have also explored solutions to the problems related to community integration. Sun [18] argued that community empowerment, a process of building awareness, enhancing abilities and developing skills, gave more community residents a fair opportunity to participate in community activities. Gao [19] suggested that community managers should actively create conditions to promote the inclusion of the floating population as participants in community management, so as to enhance their sense of belonging and help them integrate into the community. Observing that the development of cultural identity, community integration, and citizenization is a gradual process, Wang et al. [20] argued that the construction of an urban community culture should be strengthened to guide the migrant population to integrate into the community as soon as possible. Ke et al. [21] highlighted the major role of the government in the integration of migrant workers into the community. The government needs to be effective in community construction and promote the participation of the migrant population in community activities so they can integrate into the community. Zhang et al. [22] noted that previous studies of social integration were mostly limited to immigrants and paid little attention to local residents' attitudes toward immigrants. He thus advocated for a perspective on social integration as a two-way interactive process. Deng et al. [23] found that the extent of the fairness that migrants felt in the community influenced their personal integration experiences, and that their sense of community justice largely determined their integration attitude, expectations, and decisions.

\subsection{Community Integration of Tourist Immigrants}

In studying immigrants to tourist destinations, scholars have mainly focused on their motivations, their influence, and career transition after the influx and the flow pattern of the migrant population [24]. Immigrants to tourist destinations are attracted by the unique climate, environment, and local lifestyle. The movement of individuals to tourist destinations also brings families to the community $[25,26]$. The influx of new residents tends to have positive and negative effects. On the one hand, an inflow of capital and knowledge is brought by the floating population into the tourist destination. This adds to the attraction of the tourist destination, and develops or strengthens connections between the tourist destination and the new residents' former homes. On the other hand, the entry of a floating population into the tourist destination stretches the community's resources and challenges the sovereignty and interests of the native residents. The employment of the floating population in the tourist destination also reduces employment opportunities for native residents to some extent $[27,28]$.

Community integration and the influence of new tourism residents in China is a relatively recent area of research. In summarizing the work of earlier immigration scholars, Lu et al. [29] identified four dimensions to the social integration structure of tourism immigrants in Hongcun: cultural integration, identity integration, psychological integration, and economic integration. The identity integration factor mainly reflected the degree to which tourism immigrants identified themselves as "New Hongcun Villagers." He et al. [30] 
reported that the differences in cultural values between immigrants and locals and the poor living environment was hindering community integration in Jiuzhaigou, whereas a stable community economy and good business prospects were conducive to community integration. Wang et al. [9] found that tourist migrant workers in Hui Min Fang in Xi'an had less perception of positive emotions, such as happiness, and greater perception of negative emotions, such as anger, jealousy, and worry. Bai et al. [31] found in their study of the ancient town of Lijiang that the social atmosphere had a significant positive correlation with the local integration of tourism immigrants. An in-depth study of the same town by Cheng et al. [32] found that the life satisfaction of immigrants had a significant impact on their sense of local identity, and that social relations played a partial intermediary role in the relationship. Liu [33] reported that the overall degree of social integration of tourist immigrants was low. Both individual factors and entry factors affected the degree of social integration, among which individual factors were more influential, while macro and policy factors were also important.

It can be seen from the above discussion that the literature on social integration and immigrant community integration is relatively mature. Under the influence of urbanization in China, most of the studies have focused on the integration of migrant workers and new citizens into urban communities. There have been a few studies on the integration of new tourism immigrants in tourist destination communities, although the issue has begun to receive some attention in recent years. A heritage community is a particular type of community with its own characteristics in the integration of new inhabitants, and is therefore worthy of further study.

\section{Methods}

\subsection{Selection of the Research Case}

Located in the southern part of Anhui Province, the Huangshan Scenic Area is a typical mountain scenic spot, which is listed in China's top ten scenic spots together with the Great Wall and the Forbidden City. Huangshan was inscribed on the World Heritage List in 1989 for its unique natural scenery and rare structure of peaks. Tangkou town includes Tangkou community, Zhaixi community, and other four villages, which are located away from the south gate of the scenic area only $1 \mathrm{KM}$, is a typical heritage community (Figure 1). Historically, Tangkou town was a poor and isolated rural area in China where forest tea was the main crop. Since the development of Huangshan tourism in 1978, Tangkou town has been the main hub for tourists visiting the scenic area, undertakes tourist distribution, accommodation and reception functions, commercial services, and provide accommodation for the staff. The number of tourists has increased every year, people from other parts of Anhui Province or other provinces in China come to Tangkou to work in tourism-related jobs. A corresponding increase in the number of tourist service facilities and practitioners, has promoted the continuous expansion and reorganization of the community. By 1997, Tangkou town had become the largest tourist reception and distribution center of Huangshan, with nearly 400 individual businesses of all kinds in the village, including more than 200 individual hotels with 6000 beds. There is a plethora of small shops and restaurants, and the commercial facilities are extremely dense. The associated influx of migrants has led to a chaotic residential population, environmental degradation, and many social problems. 


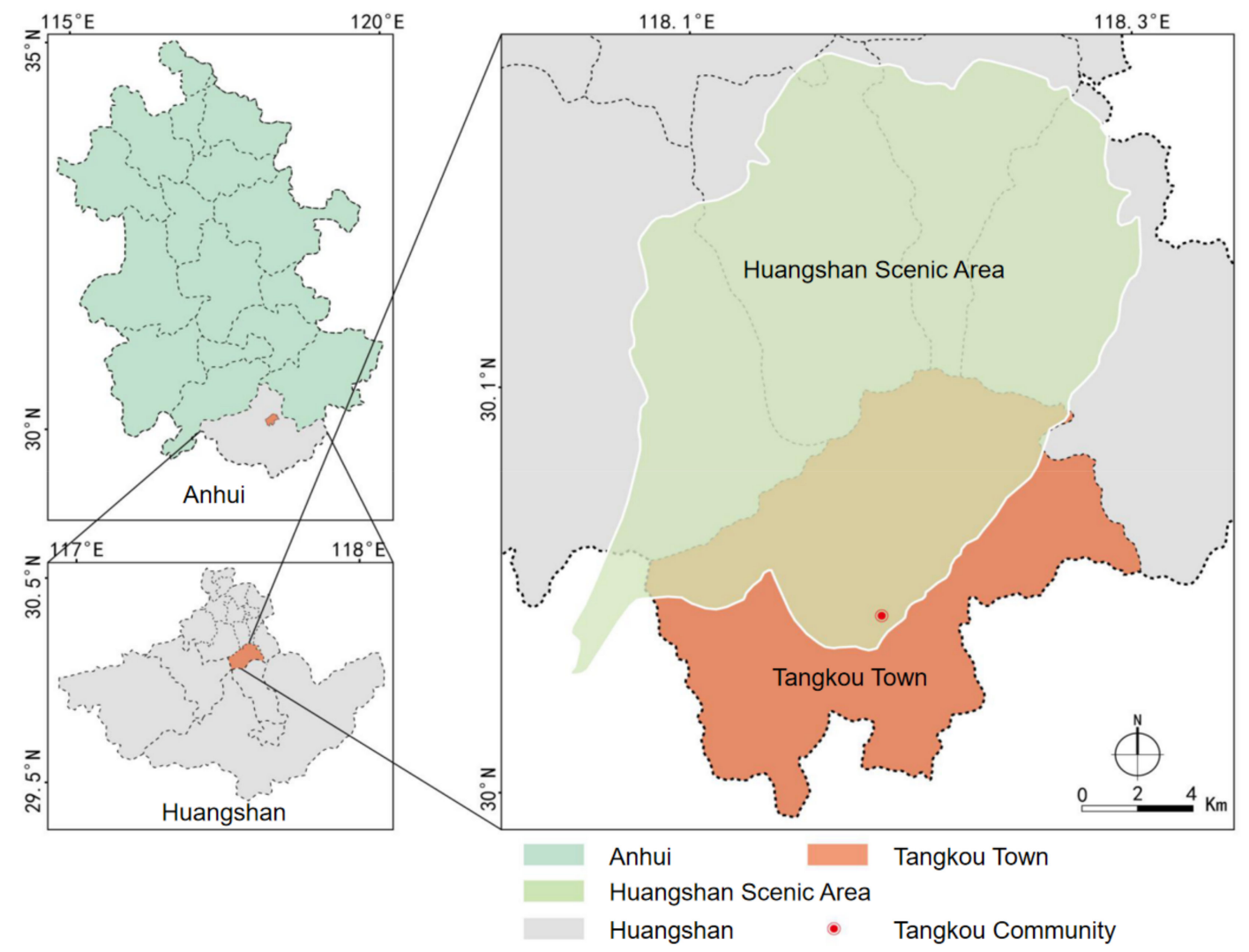

Figure 1. Location of Tangkou community, State of Huangshan city, Anhui provinces.

In an attempt to address these problems, The General Plan of Tangkou Town (1997-2010) was issued in 1997. It proposed for the first time to take Zhaixi village as a functional extension of Tangkou town that could undertake some of the functions of Tangkou community, so as to form two core functional areas of Tangkou and Zhaixi. Tangkou town has also successively built the Chengqi Villa and Zhaixi Comprehensive Service area within the Zhaixi West group, and undertaken the relocation of scenic area functional departments. Individual private owners have been encouraged to invest in the construction of a "tea culture street" and accredited tourist hotels. At the same time, the project of Zhaixi New Village was implemented to accelerate the citizenization of farmers. By the end of 2005, more than 400 households had come to Tangkou town to set up collectives and individual businesses, and the non-resident population of Tangkou community had reached more than 2000.

The construction of the Zhaxi community was not effective in alleviating the pressure on the Tangkou community. Therefore, revised plans were issued in 2005 in the form of the General Plan of Tangkou-West Zizhai and the Detailed Plan of Group Control of West Zizhai. It proposed to improve the functions of the town and completely change the image of the old city. Zhaixi Community was earmarked as the main service base and an important transportation hub of Huangshan Scenic Area. It would also absorb the excessive population and capital of Tangkou town and effectively regulate the transformation of the old town of Tangkou. This was to take place in three steps: first, a comprehensive old city reconstruction, including the comprehensive renovation of Xiaoyao Creek, the hinterland of the old city, and of the high road. Second, beginning development of the planned area in the west of the Zhaixi village, including infrastructure construction and central village construction. Third, accelerating the planning and construction of new villages for the surrounding farmers: Feicui New Residents Village, Jiulong New Residents Village, Gangcun New Residents Village and Fangcun New Residents Village. The overall aim was to optimize the layout of the whole community through the reconstruction of the 
old city and the construction of the new villages, and to guide the rational living of all types of residents, including the migrant business population.

In 2008, the third round of town master plan revision was launched, putting forward the development idea of "controlling and reforming Tangkou and developing ZhaiXi village in an orderly fashion". There were two major elements to this revision. First, it focused on the completion of road, traffic, environmental protection and other infrastructure construction, especially the completion and use of the Huangshan tourist distribution center and Dongling parking lot to optimize the overall service pattern. Second, it proposed to speed up the construction of the Zhaixi comprehensive development zone. More than a dozen departments of industry and commerce, such as taxation, fire control, hospital, middle school and water plant would be moved to Zhaixi village to transform it into the political, economic, and cultural center of the town. With the above planning adjustment, the reconstruction of the old town, the construction of the new villages and the optimization of the infrastructure, Tangkou town has gradually completed the reorganization and merger of the whole community in supporting the whole tourist development process of Huangshan Scenic Area.

In the process of community restructuring, the immigration phenomenon in Tangkou town became more and more obvious [34]. At present, the permanent population of Tangkou town is about 12,000 , of which more than $70 \%$ belong to the floating population. Most of the floating population come from She county, Anqing city, and other surrounding areas. They mainly live in Zhaxi community. Some of the floating population have bought houses in the local area and become new residents. When migrants enter Tangkou for business or to live, they bring fresh blood into the town, and also cause some problems. Some issues that have occurred and caused tension in community relations are migrants sticking together in groups, disobeying government discipline and bullying local people. These issues complicate the problem of community integration and can be used as references in research into this problem.

\subsection{Research Methods}

This study examined the community integration of new residents in heritage tourist sites, during July 2018, a sample of people, who immigrated to tourist destinations, were interviewed with respect to their perceptions of factors influencing the integration of new residents in Tangkou town.

\subsection{Grounded Theory Approach}

Quantitative research methods have been adopted in previous studies of immigrants to tourist destinations. For example, Lu et al. [29] used a questionnaire survey to study the tourism immigrants in Hongcun, and Yang et al. [1] combined field observation and interviews to examine the settlement characteristics of Qiandao Lake. However, no studies of community integration in this domain have taken a grounded theory approach.

Grounded theory consists of a prescribed set of procedures for analyzing data and building theoretical frameworks, it is the commonly used qualitative methods in tourism research [35]. This approach set out to discover new theoretical insights and innovations, usually make use of in-depth interview techniques for collecting data. Grounded theory and intensive interviewing allows an in-depth exploration of a topic and is considered useful for the interpretive inquiry [36]. This paper adopts grounded theory, an exploratory research technique that proceeds from top to bottom, to better explore the community integration of new residents in the process of heritage community reorganization. Through data collection, field investigation and in-depth interviews, the author directly started from observation and summarized the experiences emerging from the original data. A theoretical model of the impact of community integration of new residents was then constructed by analyzing the relationships between these concepts. 


\subsection{Data Collection}

The author conducted field surveys and interviews in various communities in Tangkou town, semi-structure interviews with 37 new residents from the restructured Tangkou and Zhaixi communities were conducted in July 2018 (see Table 1 for the demographic characteristics). Through in-depth interviews, about 30,000 words of audio recorded were collected. Because of the small sample size, we treated referrals and participants with some caution. Along with the findings of the field survey, relevant meeting information and some government planning materials were collected. This secondary information helped to deepen the understanding and grasp of the case, ensures the objectivity of the data, made it easier to view the problem from different angles, and improved the reliability of the coding output.

Table 1. Demographic characteristics of the sample.

\begin{tabular}{|c|c|c|c|c|c|c|c|c|c|c|c|}
\hline & \multicolumn{2}{|c|}{ Gender } & \multicolumn{5}{|c|}{ Age } & \multicolumn{4}{|c|}{ Education Level } \\
\hline & Male & Female & $<20$ & $20-30$ & $31-40$ & $41-50$ & $>50$ & $\begin{array}{c}\text { Primary } \\
\text { School }\end{array}$ & $\begin{array}{c}\text { Junior } \\
\text { High } \\
\text { School }\end{array}$ & $\begin{array}{l}\text { High } \\
\text { School }\end{array}$ & $\begin{array}{c}\text { College } \\
\text { and } \\
\text { Above }\end{array}$ \\
\hline Number & 12 & 25 & 1 & 5 & 9 & 10 & 12 & 10 & 10 & 10 & 7 \\
\hline Percentage & $32.4 \%$ & $67.6 \%$ & $2.7 \%$ & $13.5 \%$ & $24.3 \%$ & $27 \%$ & $32.5 \%$ & $27 \%$ & $27 \%$ & $27 \%$ & $19 \%$ \\
\hline
\end{tabular}

\section{Research Process}

\subsection{Open Coding}

Open coding refers to the process of identifying phenomena, defining concepts, discovering categories, and collecting problems [15]. The work carried out by the researcher in coding is tedious and involves many iterations. It is necessary to analyze the obtained textual information word by word, sentence by sentence. The concepts obtained at the beginning are relatively scattered, and only after repeated concept extraction can the concept be abstracted and theorized. For open coding, 32 of the interviews were used as the research sample, and five interviews were set aside for the later saturation test. The interview source materials were organized at the beginning of the coding, with 577 items of separate textual interview information identified. Each text was coded with the symbol $F T x-y$, where $x$ identified the interviewee and $y$ the item of text. For example, the first piece of interview information from the first interviewee was coded as FT1-1. Open coding identified 84 concepts involved in the integration of new residents into the communities. Due to limited space, only some examples are shown in Table 2. Most of the initial concepts were scattered and straightforward, and needed further clustering to categorize the concepts. After clustering the 84 concepts and categorizing those with similar connotations together, 16 categories were derived (for example, "role of government", "convenience and benefits for people", and "expectations on the government") and prefixed with $A a$ (see Table 3). These 16 categories were the factors that most influenced the community integration of new residents according to the analysis of the interview data. 
Table 2. Schematic of partial concept extraction.

\begin{tabular}{|c|c|c|}
\hline Original Interview Materials & Abstract & Conceptualization \\
\hline \multirow{5}{*}{$\begin{array}{l}\text { "... I don't feel that the government provides any } \\
\text { convenience for me to live or work, I can hardly say that I } \\
\text { am satisfied with it ..."; “... Many tourists are cheated here, I } \\
\text { hope the government will strengthen supervision ..."; “... In } \\
\text { some ways, operators are in a weaker position, but the } \\
\text { government doesn't have any protection for the service } \\
\text { sector ..."; “... The government basically doesn't care about } \\
\text { soliciting ..."; "The same operators here are saturated, but } \\
\text { the government hasn't come up with any solutions at all ..." }\end{array}$} & $\begin{array}{l}\text { Z1 Not satisfied with the } \\
\text { government in providing } \\
\text { convenience }\end{array}$ & $\begin{array}{l}\text { A1 Dissatisfaction with } \\
\text { government }\end{array}$ \\
\hline & $\begin{array}{l}\text { Z2 Strengthen } \\
\text { government supervision }\end{array}$ & A2 Regulatory intensity \\
\hline & $\begin{array}{l}\text { Z3 Government not } \\
\text { providing protection }\end{array}$ & A3 Government protection \\
\hline & $\begin{array}{l}\text { Z4 Government } \\
\text { mismanagement }\end{array}$ & $\begin{array}{l}\text { A4 Government } \\
\text { mismanagement }\end{array}$ \\
\hline & Z5 Government inaction & A5 Government action \\
\hline
\end{tabular}

Table 3. Axial coding analysis.

\begin{tabular}{|c|c|c|}
\hline Category & Standard & Concepts \\
\hline \multirow{3}{*}{$\begin{array}{l}\text { Support for the } \\
\text { government }\end{array}$} & Aa1 Government action & $\begin{array}{l}\text { a1 Government satisfaction; a2 Regulatory intensity; } \\
\text { a3 Protection measures; a4 Mismanagement; } \\
\text { a5 Government action }\end{array}$ \\
\hline & $\begin{array}{l}\text { Aa2 Convenience and benefits } \\
\text { for people }\end{array}$ & $\begin{array}{l}\text { a6 Convenience of life; a7 Job opportunities; a8 Simplified } \\
\text { procedures; a9 Subsistence allowance discount }\end{array}$ \\
\hline & Aa3 Expectations on the government & $\begin{array}{l}\text { a10 Improve service level; a11 People's livelihood; } \\
\text { a12 Government reorganization; a13 Equality; } \\
\text { a14 Government subsidies; a15 Tourism promotion }\end{array}$ \\
\hline \multirow{5}{*}{ Economic integration } & Aa4 Living status & $\begin{array}{l}\text { a16 With family; a17 Living alone; a18 Purchased house; } \\
\text { a19 Long-term residence; a20 Renting premises }\end{array}$ \\
\hline & Aa5 Operating status & $\begin{array}{l}\text { a21 Operating a restaurant; a22 Hard to rent a house; } \\
\text { a23 Competition is fierce; a24 Normal competition; } \\
\text { a25 Non-interference with each other; a26 Losing money; } \\
27 \text { Rent is expensive }\end{array}$ \\
\hline & Aa6 Personal income perception & $\begin{array}{l}\text { a28 Income satisfaction; a29 Improvement of living } \\
\text { standards; a30 Improvement of income }\end{array}$ \\
\hline & Aa7 Operating problems & $\begin{array}{l}\text { a31 Operating saturation; a32 Price war; a33 Vicious } \\
\text { competition; a34 Soliciting behavior; a35 Underfunded; } \\
\text { a36 Shortage of labor }\end{array}$ \\
\hline & Aa8 Operating measures & a37 Price reduction; a38 Online promotion \\
\hline \multirow{4}{*}{ Community environment } & Aa9 Natural environment & $\begin{array}{l}\text { a39 Garbage disposal; a40 Living environment; a41 Sanitary } \\
\text { conditions; a42 Roads; a43 Greening; a44 Garbage collection; } \\
\text { a45Purification plant; a46 Sewer; a47 Noise }\end{array}$ \\
\hline & Aa10 Infrastructure & $\begin{array}{l}\text { a48 Entertainment facilities; a49 Uneven distribution; } \\
\text { a50 Lack of bus stops; a51 No plaza; a52 Fitness and leisure } \\
\text { facilities; a53 Traffic inconvenience; a54 Lack of parking } \\
\text { spaces; a55 No park }\end{array}$ \\
\hline & Aa11 Public services & $\begin{array}{l}\text { a56 Public service facilities; a57 Medical care; } \\
\text { a58 Educational facilities; a59 Renovation of old houses }\end{array}$ \\
\hline & Aa12 Tourism development & $\begin{array}{c}\text { a60 Cheating customers; a61 Stagnation; a62 Industry not } \\
\text { developing well }\end{array}$ \\
\hline
\end{tabular}


Table 3. Cont.

\begin{tabular}{|c|c|c|}
\hline Category & Standard & Concepts \\
\hline \multirow{4}{*}{ Psychological integration } & Aa13 Motivation of migration & $\begin{array}{l}\text { a63 Large number of tourists; a64 Pure mind; a65 Large } \\
\text { tourist flow }\end{array}$ \\
\hline & Aa14 Daily communications & $\begin{array}{c}\text { a66 Contacts; a67 Interactions; a68 Willingness to } \\
\text { communicate; a69 No conflict; a70 Harmony; a71 People } \\
\text { have good personalities; a72 People are simple; a73 No } \\
\text { contradictions }\end{array}$ \\
\hline & Aa15 Sense of belonging & $\begin{array}{l}\text { a74 Sense of belonging; a75 Emotional connection; a76 } \\
\text { Second hometown; a77 Close to home; a78 Half of the local } \\
\text { people; a79 Familiar with local life; a80 Adapted to local life; } \\
\text { a81 Unfamiliarity }\end{array}$ \\
\hline & Aa16 Future plans & $\begin{array}{l}\text { a82 Off-site development; a83 Optimistic attitude; } \\
\text { a84 Change business }\end{array}$ \\
\hline
\end{tabular}

\subsection{Axial Coding}

Based on open coding, further comparisons and combinations can make the coding more theoretically sound and representative. Axial coding was therefore carried out by further analyzing and summarizing the 16 derived concepts. The result was the identification of four main categories related to the community integration of new residents: support for the government, economic integration, community environment, and psychological integration (Table 3). These four main categories and 16 categories together constitute the factors influencing the integration of new residents in the process of heritage community restructuring.

The chain of evidence for support for the government (Figure 2a) is as follows: Government actions are the precondition for new residents to support the government. Relevant laws and regulations issued by the government to improve the lives of the local residents as well as measures for the convenience and benefit of the people are the intermediary conditions for residents to form government support. Placing expectations on the government is a strategy taken by the new inhabitants toward the government.

The chain of evidence for economic integration (Figure 2b) is as follows: The living and operating status of the residents are the prerequisites for the economic integration of new residents. New residents' perceptions of personal income and operating problems are intermediary conditions for economic integration. The measures proposed by the new residents to address the operating problems are the action strategies of economic integration.

The chain of evidence for community environment (Figure 2c) is as follows: The natural environment that is experienced directly in the community is the precondition for the community environment. The infrastructure and public services provided by the government and the community provide a solid foundation for the community environment of the new residents, and serve as the intermediary conditions for the community environment. Tourism development is an action strategy for improving the community environment.

The chain of evidence for psychological integration (Figure 2d) is as follows: The motivation for moving in determines whether residents have chosen to join the community, which is a prerequisite for psychological integration. Daily communication is the intermediary condition for psychological integration. A sense of belonging and planning for the future are action strategies for psychological integration. 


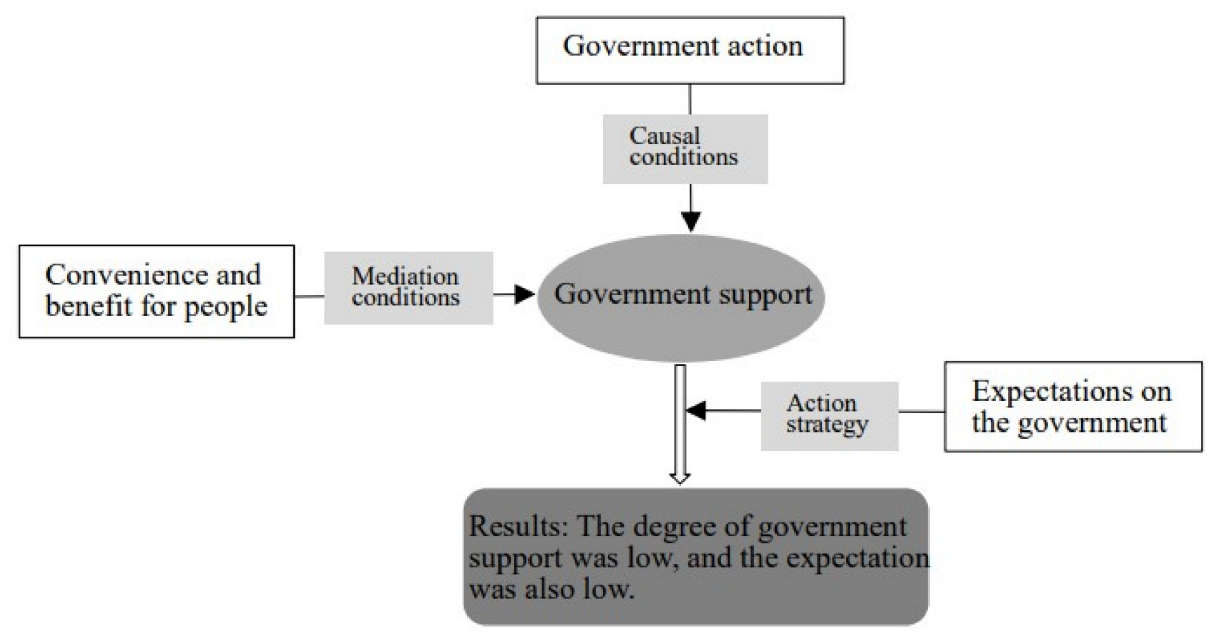

(a)

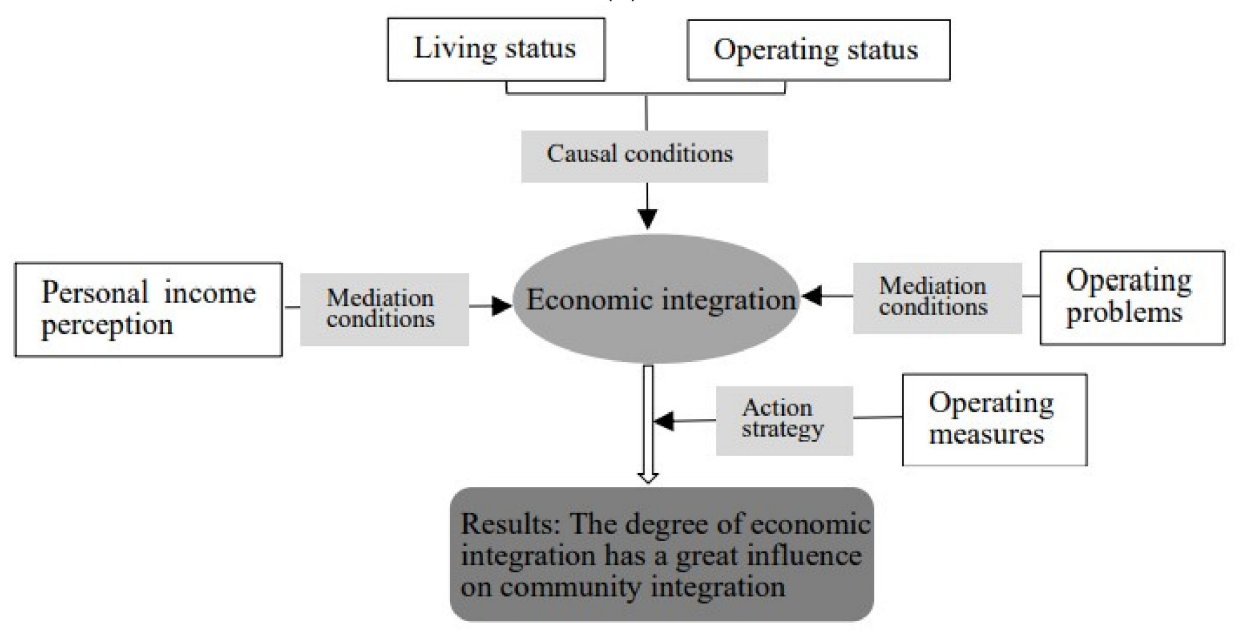

(b)

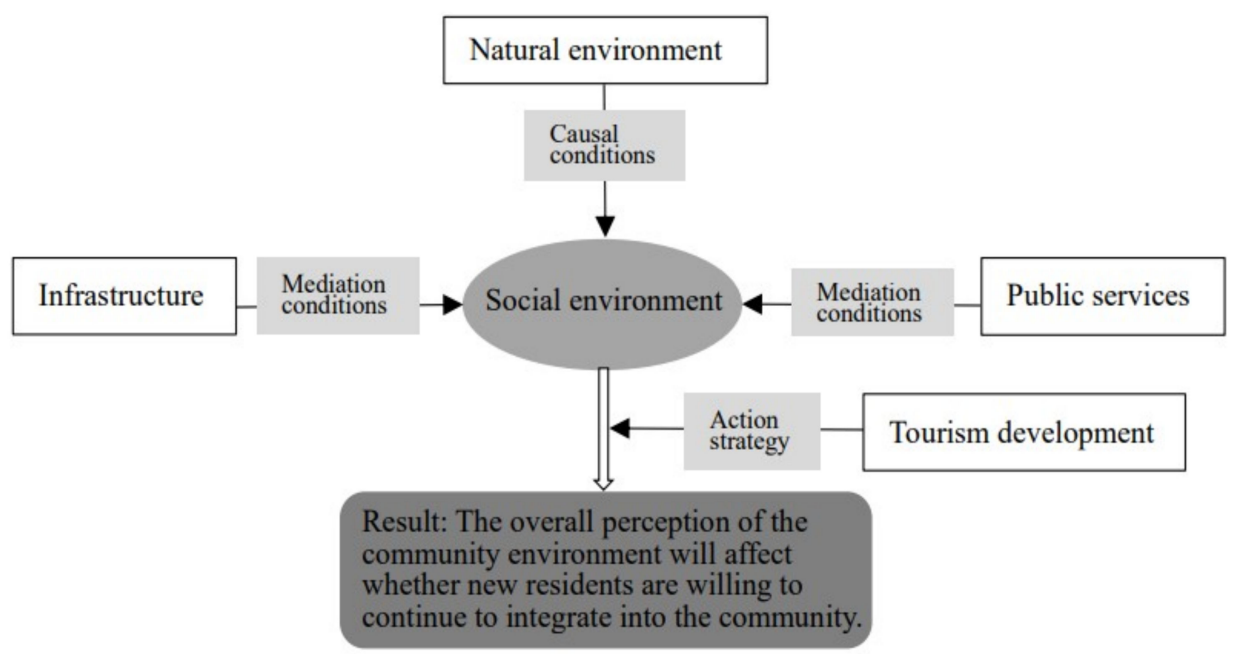

(c)

Figure 2. Cont. 


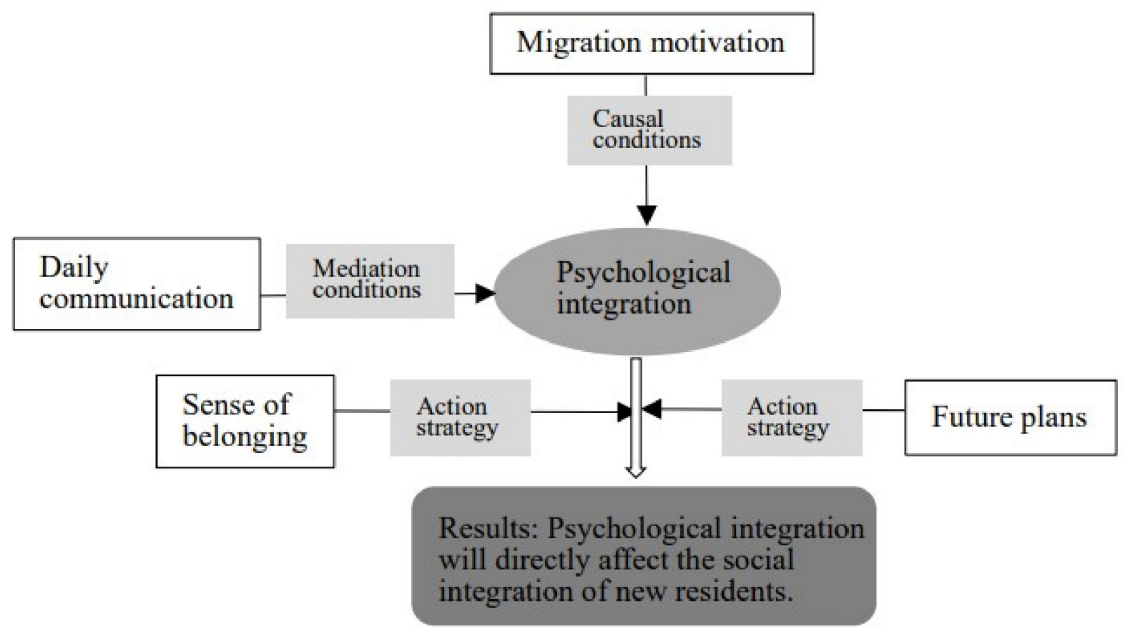

(d)

Figure 2. (a) The chain of evidence for support for the government. (b) The chain of evidence for economic integration. (c) The chain of evidence for community environment. (d) The chain of evidence for psychological integration.

\subsection{Selective Coding}

Selective coding is the final extraction process of the data extracted from the first two processes, which is the mining of a "core category." The four main categories of support for the government, economic integration, community environment, and psychological integration extracted by axial coding were further analyzed and integrated. At the same time, the original data records were compared in depth. Through this process, the core category of "community integration of new residents" was extracted, with the evidence chain shown in Figure 3.

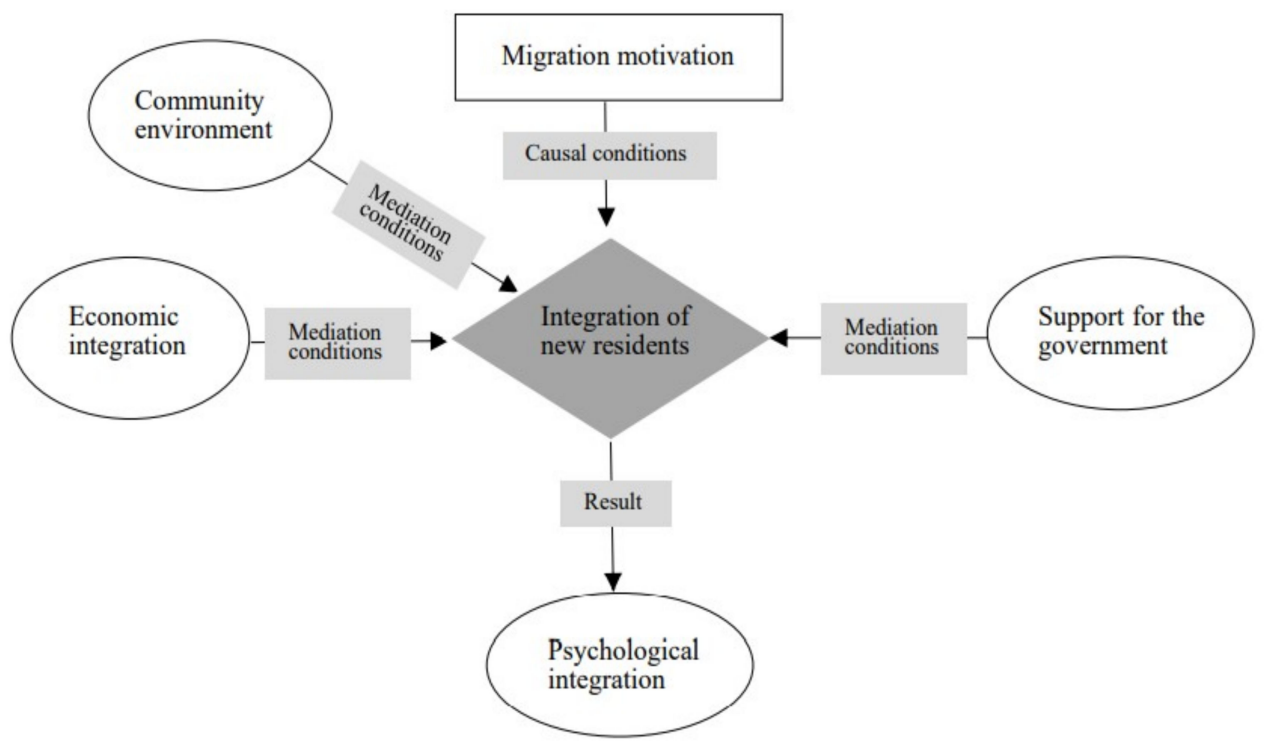

Figure 3. The chain of evidence for the four core categories and the integration of new residence.

\subsection{Saturation Test}

As mentioned above, five interview outlines were randomly selected for retention for use in saturation testing. These outlines were used to test for theoretical saturation, and none of the data were found to exceed the categories and concepts extracted in the above theoretical model. Therefore, the theoretical model constructed in this study was considered saturated. 


\section{Research Results}

After using grounded theory to study the integration of new residents in a heritage community, a number of factors were found to influence the outcome of the community integration of the new residents. The 84 concepts, 16 categories, and 4 main categories extracted from the data are summarized below. Verbatim quotes from the new residents are used to support the results.

\subsection{Support for the Government}

Support for the government comprises three categories: government action, convenience and benefits for people, and expectations on the government. Most of the new residents showed a negative tendency in their subjective perception of the government's actions. For example, one interviewee stated that "we are far from satisfied with what the government has done, and the government has not provided any convenience for our work or life" (FT4-6). Most of the new residents point out that "The current rural homestead tourism utilization policy is not conducive to non-local operators" (FT15-10, FT16-8 and FT20-16). There were generally less clearly negative feelings in regard to government obvious with greater distance from the core of the scenic area. One interviewee complained that "the government only provides more convenience to those places on the tourist routes, but does not care about remote areas at all" (FT5-9). However, the expectations placed on the government tended to be positive, in the belief that the government plays an important role in the development of the community. This can be seen in the direct statement of one interviewee that "Tourists are often cheated here, so they hope the government will strengthen supervision" (FT2-19).

\subsection{Economic Integration}

Economic integration comprises the five categories of living status, operating status, personal income perception, operating problems, and operating measures. New residents in Tangkou town are mainly either renting or have purchased a house: seven of the interviewees indicated that they had bought houses in the local area, and 23 said that they rented or that their employer provided a house for them. The interviewees who had bought houses were significantly more satisfied with the local area than renters. "I've bought a house in Taokou town and I feel like a local now" (FT35-19). "The cost of renting a house is high, and the operating pressure is great in the off-season" (FT29-4). In regard to problems with their business operations, one typical statement was that "local business competition exists, and we are far away from tourist attractions, so business is not good, so everyone has to reduce the price to fight the price war" (FT8-18). All 37 respondents mentioned satisfaction or dissatisfaction with their incomes. Sixteen respondents said that they felt "OK" or "satisfied" with their current income, while the other 21 said that they were not satisfied with their current income. During the interviews, many complaints were aired about problems operating businesses in the local area. For example, one respondents said that "local economic development is not balanced, and some local businesses are doing well while others are not" (FT3-9). One respondents said that "Non-local operators are in a weak position here and will encounter more business difficulties than locals" (FT16-15). Facing various problems with their business operations, the interviewees indicated that they would consider various solutions, including "price reductions and online promotions" (FT8-17).

\subsection{Community Environment}

Community environment is the external environment that new residents can feel most directly after they move to a new area. It is an important factor in the integration of new residents in communities, and comprises the four categories of natural environment, infrastructure, public services, and tourism development. Tangkou town is located at the foot of Huangshan with beautiful mountains and water. Unsurprisingly, therefore, many interviewees mentioned "good environment", "good air", and "good greenery" (FT3-12, 
FT37-2 and FT6-12). However, one interviewee also stated that "the local garbage disposal still needs to be improved. The garbage piled up not only has a bad impact on the overall local environment but also emits a foul smell, affecting the living quality of residents" (FT612). With the gradual integration of urban and rural areas due to economic development, another interviewee commented that "The infrastructure of Tangkou town is not far behind that of big cities, but it is still insufficient in terms of entertainment facilities" (FT18-12). To some extent, this will deter potential new residents from moving to Tangkou town. The new residents also repeatedly mentioned "poor public services such as local community hospitals and schools" (FT1-10, FT6-10, FT25-9, and FT27-6). This will directly affect new residents by giving them cause to worry about their own and their children's future, and is likely to hinder new residents' integration into the community to some extent.

\subsection{Psychological Integration}

Psychological integration is the most important factor affecting the integration of new residents in the community, and it is also the most intuitive factor for measuring whether and to what extent new residents are integrated into their new community. It comprises the four categories of migration motivation, daily communication, sense of belonging, and future plans. The original intentions of the interviewees in moving to Tangkou town varied, with some representative examples looking for business opportunities ("We came here because of the relatively good tourism development" (FT1-3)), to stay and develop a better life ("My family and friends are all here. They call me to come here [to develop]. After a long time, I have stayed here") (FT8-3), and for work ("I came here (to work) because it is close to my home and the development is good" (FT23-3)). More than half of the interviewees said that although there was a long settling-in period, their experience had basically met their original intention of moving there. Of the 37 interviewees, more than 20 said that the locals were "honest" and "easy to get along with" (FT37-11 and FT5-11). In addition, some interviewees said that they had little contact with the local residents because everyone had their own affairs, but "we are all willing to communicate with local people, and we are also willing to help them if they need help" (FT12-8). It can be seen that the new residents of Tangkou town have a relatively strong desire to communicate with the local residents even if they did not get along that well with them. Among the new residents interviewed, some had lived in the area for more than 20 years, while other had just arrived in Tangkou less than one year before the interview. When asked how they felt about the local area, 25 interviewees said that they had a good relationship with the local area and had basically taken it as their second hometown. After decades of development, major changes have taken place in Huangshan, both economically and in other aspects. In this respect, it is interesting to note that most of the interviewees believed that the development of Huangshan was declining. Nonetheless, only a small number of respondents said they were ready to move to another location or had thoughts of changing their business.

\section{Conclusions and Discussion}

\subsection{Conclusions}

In the process of tourism development, the issue of community restructuring and inhabitant adaptation problem are important issues to be solved urgently, which is of great significance for promoting the sustainable development of World Heritage sites. However, the current research on the series of problems caused by the reorganization of rural communities in typical heritage sites in China is lacking [37]. More than 10 years after the community reorganization of Tangkou town, there are still many problems with the community integration of new residents, which has become an area of focus for the local government. This study takes the new inhabitants of the community reorganized in Tangkou Town as the research object, obtains first-hand data through field research and sampling in-depth interviews, uses the qualitative research method of grounded theory to summarize the factors and paths that affect the integration of new inhabitants into the community. 
The four influencing factors found to affect the community integration of new residents are support for the government, economic integration, community environment, and psychological integration. Support for the government, economic integration, and community environment are external factors. In terms of government factor, most of the new residents point out that the government and relevant policies play an important role in the process of community restructuring, but the current rural homestead tourism utilization policy, supervision and management policies are unfavorable to the new residents. So they put forward more expectations to the government. In terms of economic integration factor, new residents who have bought houses show better integration satisfaction than those who rent houses. When the income and operation status are good, the degree of community integration is high. They also point out that the new residents will encounter more business problems than the local people, and the only way to solve those problems is to reduce the price, which will cause the dissatisfaction of the local operators and increase the difficulty of community integration. The community environment factor are the most intuitively felt by new residents. The beautiful natural environment and high quality air quality of Tangkou Town attract new residents. However, supporting facilities and public welfare in the community hinder their integration.

Psychological integration is the internal factor that affects the community integration of new inhabitants. It runs through the whole process of community integration of new residents and is the most important factor. When a person decides to move into a new community, there must be some motivation behind the decision. In the process of living in the heritage community and engaging in business or service activities, they become new inhabitants and are affected by various external factors, which leads to their psychological changes. When new residents feel that the external conditions are more friendly to them, they have a stronger sense of closeness to the community. Therefore they can integrate into the community well. When the new inhabitants feel that the external conditions are not friendly to them, and they suffer from various problems and obstacles in their daily life and business life, they will feel estranged from the community, and then have the idea of escaping from the community. This leads to the theoretical model of the influence of community integration of new residents, as shown in Figure 4.

\subsection{Discussion}

Based on the case study of Tangkou town, this paper presents a theoretical model of the influences on new residents' community integration that is applicable to heritage sites with a similar developmental status to Tangkou. This paper goes beyond the literature in proposing two new influencing factors in the community integration of new residents: support for the government and community environment. The model constructed for the relationship between the four factors enriches and advances relevant theories and contributes to research on the influences on the integration of new residents into communities at heritage sites. The conclusions of this paper are helpful for promoting the integration of new residents into heritage communities and thus for the sustainable development of local economies and societies.

In the current social situation in China, new residents carry out various business activities after moving to heritage sites. The interviewees expressed many issues and concerns relating to the economic integration. Due to the seasonal nature of tourism, and a serious homogenization problem in the current commercial operation of heritage sites, new residents at tourism sites often encounter great challenges in operating businesses. Meanwhile, home ownership is an important factor in Chinese society and can also affect the sense of peace and stability of new residents. Therefore, in relation to the influencing factor of support for the government, they expected the government to take strong measures to help them solve problems doing business and to improve their lives. Complaints related to the community environment further demonstrated the dissatisfaction of the new residents with the business and living environment. These three external factors are 
internalized into the psychological integration factors of new residents and ultimately affecting their decision on future integration or withdrawal from the community.

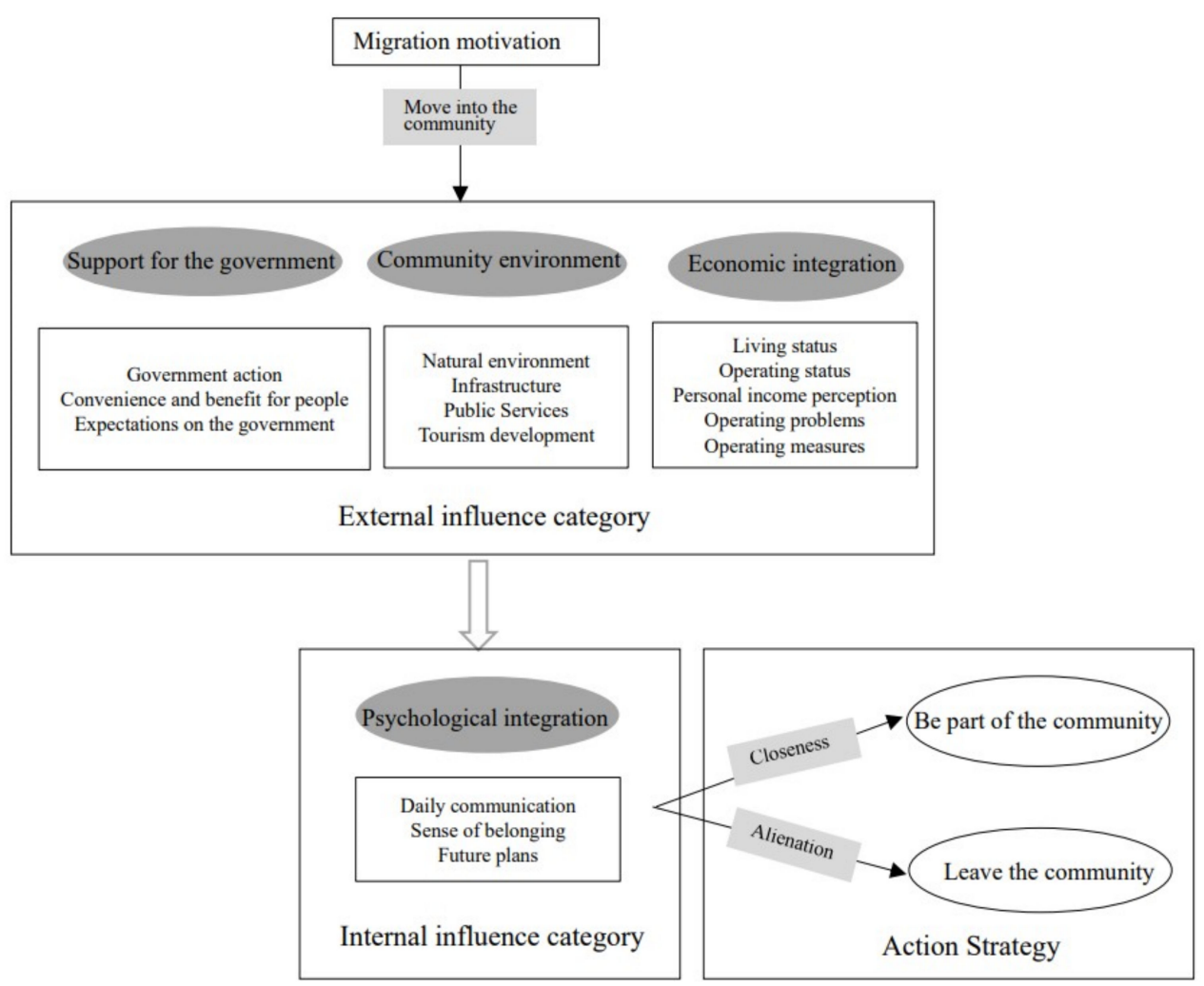

Figure 4. Theoretical model for the influences on the community integration of new residents.

The four elements of community integration are based on the examination by new residents of their business and living conditions and overall reflect the pursuit of a better and happier life. After 40 years of reform and opening up, China has achieved rapid economic growth and essentially completed building a well-off society. However, the country is still confronted with a contradiction between unbalanced and inadequate development and the ever-growing demand of its people for a better life. The social integration of new residents in the heritage site reveals the current social contradictions in China. At the same time, it encourages the promotion of economic, social, and ecological progress in the new era, so that everyone can share the fruits of development and gain a sense of happiness and progress in their life.

\section{Limitations and Further Developments}

As an exploratory study, this study tries its best to seek the truth and reliability of the conclusion, but there are still two limitations. First, the case of this study was chosen as Tangkou Town, which is a typical rural heritage site community in southern China. However, whether the conclusions obtained from the study are applicable to the heritage site communities in northern or northwestern China remains to be further tested. Second, conflicts between aboriginal people and new inhabitants in the process of community restructuring and development also affect the sustainable development of heritage sites. However, due to the problem of research perspective, this part has not been included in this study for the time being.

In the future, different locations or different types of heritage sites can be selected for comparative analysis to discuss the similarities and differences in the process of community restructuring in heritage sites. In addition, the problems triggered by the integration of 
old and new residents in the process of community development can also provide more empirical evidence for the sustainable development of heritage sites.

Author Contributions: W.W. contributed to the conceptualization and drafting of the manuscript, Y.D. processed the data and writing editing, F.Q. contributed to supervision. All authors have read and agreed to the published version of the manuscript.

Funding: This research is funded by the Ministry of Education in China (MOE) project (19YJA630088).

Informed Consent Statement: Informed consent was obtained from all subjects involved in the study.

Data Availability Statement: Not applicable.

Acknowledgments: The author(s) disclosed receipt of the following financial support for the research, authorship, and/or publication of this article: This work was supported by the Ministry of Education in China (MOE) Project of Humanities and Social Sciences (19YJA630088).

Conflicts of Interest: The authors declare no conflict of interest.

\section{References}

1. Yang, X.Z.; Sun, J.D.; Lu, L. The spatial characteristics and social effects of the settlement of tourist destinations in Qiandao Lake. Acta Geogr. Sin. 2018, 73, 276-294. [CrossRef]

2. Yue, Z.S.; Du, H.F.; Li, S.Z. The concept, theory and application of contemporary Western social integration research. J. Public Manag. 2009, 6, 114-121.

3. Park, R.E. Human migration and the marginal man. Am. J. Sociol. 1928, 33, 881-893. [CrossRef]

4. Hurh, W.M.; Kwang, K.C. Adhesive sociocultural adaptation of Korean immigrants in the U.S.: An alternative strategy of minority adaptation. Int. Migr. Rev. 1984, 18, 188-216. [CrossRef]

5. Liang, B.; Wang, H.Y. Review of studies on social integration of foreign immigrants. J. Gansu Adm. Inst. 2010, 2, 18-27. [CrossRef]

6. Greenman, E.; Xie, Y. Is assimilation theory dead? The effect of assimilation on adolescent well-being. Soc. Sci. Res. 2008, 1, 109-137. [CrossRef] [PubMed]

7. Gorden, M.M. Assimilation in American Life; Oxford University Press: New York, NY, USA, 1964. [CrossRef]

8. Dörr, S.; Faist, T. Institutional conditions for the integration of immigrants in welfare states: A comparison of the literature on Germany, France, Great Britain, and the Netherlands. Eur. J. Political Res. 1997, 31, 401-426. [CrossRef]

9. Wang, S.Y.; Bai, K. Local attachment and happiness of tourist migrant workers in Huifang, Xi'an. Tour. Trib. 2017, 31, 12-27.

10. Yang, Z.; Lu, L. Analysis on the behavior characteristics of tourist labor migration in Jiuhuashan mountain. Resour. Dev. Mark. 2007, 2, 171-175. [CrossRef]

11. Xiong, J. The influence of migrant workers' urban living style on community integration. Probe 2018, 2, 152-158. [CrossRef]

12. Bauder, H.; Sharpe, B. Residential segregation of visible minorities in Canada's gateway cities. Can. Geogr. 2010, 46, 204-222. [CrossRef]

13. Yetim, N.; Yetim, Ü. Sense of community and individual well-being: A research on fulfillment of needs and social capital in the Turkish community. Soc. Indic. Res. 2014, 114, 93-115. [CrossRef]

14. Brown Natalya, R. Housing experiences of recent immigrants to Canada's small cities: The case of North Bay, Ontario. J. Int. Migr. Integr. 2017, 18, 719-747. [CrossRef]

15. Tian, K. Investigation, analysis and reflection on migrant workers' urban adaptability. Soc. Sci. Res. 1995, 5, 90-95.

16. Zhou, H. Measurement and theoretical consideration of social integration of floating population. Popul. Res. 2012, 36, 27-37.

17. Yang, J.H. Discuss social integration. J. Jiangsu Adm. Inst. 2016, 6, 64-72.

18. Sun, J.X. Empowerment theory and the construction of community capability in the development of tourism. Tour. Trib. 2018, 23, 22-27. [CrossRef]

19. Gao, C.F. Participatory community management of urban floating population. J. Social. Theory Guide 2001, 4, 41-42. [CrossRef]

20. Wang, L.X.; Wang, L.W.; Lui, D.Q. Cultural identity, community integration and citizenization: An effective path for the new generation of migrant workers to integrate into the city-Based on the survey on the cultural construction of urban community in Q city, F province. Acad. J. Jinyang 2013, 2, 101-107. [CrossRef]

21. Ke, Y.; Ke, H. Analysis of citizenization of migrant workers from the perspective of community integration. Rural Econ. 2014, 8, 105-109.

22. Zhang, W.H.; Liu, L. Residential isolation between urban migrants and local residents and its impact on the evaluation of social integration. Jianghai Acad. J. 2015, 6, 114-122.

23. Deng, R.; Ran, G.H. What are the differences between the two generations of migrant workers in their sense of community justice?-An empirical study on migrant workers' integration into urban communities. J. Public Manag. 2017, 14, 89-103. [CrossRef]

24. Wang, F.; Su, Q. Study on the migration of foreign population in tourist destinations. J. Nanchang Norm. Univ. 2014, 35, 48-52. [CrossRef] 
25. Ladkin, A. Exploring tourism labor. Ann. Tour. Res. 2011, 38, 1135-1155. [CrossRef]

26. White, A.; Ryan, L. Polish "temporary" migration: The formation and significance of social networks. Eur. Asia Stud. 2008, 60, 1467-1502. [CrossRef]

27. Flynn, A.; Marsden, T.K. Rural change, regulation and sustainability. Environ. Plan. A 1995, 27, 1180-1192. [CrossRef]

28. Halseth, G.; Rosenberg, M.W. Cottagers in an urban field. Prof. Geogr. 1995, 47, 148-159. [CrossRef]

29. Lu, S.; Zhang, Y.C.; Wang, L.L. Research on the social integration structure and its influencing factors of ancient village tourism immigrants-A case study of world cultural heritage Hong Cun. Hum. Geogr. 2017, 32, 138-145. [CrossRef]

30. He, Y.W.; Xu, L.M. Social integration structure and influencing factors of tourist labour migration in natural sightseeing places. J. Anhui Agric. Univ. (Soc. Sci. Ed.) 2007, 26, 72-79.

31. Bai, K.; Wang, X.N. Study on the influence of social atmosphere on the local integration of tourist workers and immigrants-A case study of Lijiang Ancient City. Hum. Geogr. 2018, 33, 133-142. [CrossRef]

32. Cheng, J.J.; Chen, Z.G.; Yuan, C. A study on the relationship between life satisfaction and local identity of tourism business owners' immigrants-A case study of Lijiang Ancient City. J. Zhejiang Univ. (Sci. Ed.) 2018, 45, 634-641. [CrossRef]

33. Liu, J.Q. Consumption-oriented business real estate and social integration of tourism immigrants. Shanghai Real Estate 2019, 1, 30-34.

34. Yang, Z.; Cheng, H. Research on micro-driving force of migration of tourism business owners in China's natural sightseeing destinations-A case study of Tangkou in Huangshan. Geogr. Res. 2018, 37, 954-966. [CrossRef]

35. Hardy, A. Using grounded theory to explore stakeholder perceptions of tourism. J. Tour. Cult. Chang. 2005, 3, 108-133. [CrossRef]

36. Nunkoo, R.; Ramkissoon, H. Stakeholders' views of enclave tourism: A grounded theory approach. J. Hosp. Tour. Res. 2013, 40, 557-558. [CrossRef]

37. Yang, X.Z.; Yang, Z.; Zhu, Y. Rural settlements functional transformation and spatial restructuring in world heritage sites: Take Tangkou, Zhaixi and Shancha as examples. Geogr. Res. 2020, 39, 2214-2232. 